\title{
FEATURE The 2011 Ohio River flooding of the Cache River Valley in southern Illinois
}

\author{
Kenneth R. Olson and Lois Wright Morton
}

n late April and early May of 2011, the Ohio River briefly reclaimed its ancient floodway through southern Illinois to the Mississippi River as heavy rains and early snowmelt over the eastern Ohio Basin raised the Ohio River gage at Cairo, Illinois, to $18.7 \mathrm{~m}$ (61.72 ft) (NOAA 2012). The Cache River Valley, carved by the ancient Ohio River prior to the last glacial period approximately 14,000 years ago, once again filled with a torrent of waters as the Ohio River at flood stage pushed into and reversed the flow of the Post Creek Cutoff, a diversionary ditch designed to drain wetlands for agriculture (figure 1). Concurrently, the Mississippi River on the western edge of the valley was backed up and threatened the integrity of the Len Small and Fayville levee systems to protect agricultural lands, Horseshoe Lake, homes, and rural towns (Olson and Morton 2013a). As Ohio River floodwaters rushed into the Main Ditch from the east, the rainswollen, meandering Cache River and the extensive drainage systems throughout the valley, already filled to capacity, overflowed the internal system of levees and flooded Massac, Pulaski, and Alexander counties as far west as Olive Branch and Horseshoe Lake. To explain the convergence of the flooding events southern Illinois residents experienced in 2011 requires understanding the history and geomorphic features of the Cache River Basin.

\section{THE ANCIENT OHIO RIVER AND HISTORIC GEOLOGICAL FEATURES OF THE CACHE RIVER VALLEY}

The modern day Cache River Valley of southern Illinois has a string of tupelo (Nyssa L.)-cypress (Taxodium distichum L.) swamps, sloughs, and shallow lakes, remnants of the ancient Ohio River whose confluence with the Mississippi River

Kenneth R. Olson is professor of soil science in the College of Agricultural, Consumer, and Environmental Sciences, University of Illinois, Urbana, Illinois, and Lois Wright Morton is professor of sociology in the College of Agriculture and Life Sciences, lowa State University, Ames, lowa. was once northwest of Cairo, Illinois. The ancient Cache RiverValley, $80 \mathrm{~km}(50 \mathrm{mi})$ long and 2.5 to $5.0 \mathrm{~km}$ (1.5 to $3.0 \mathrm{mi}$ ) wide, was formed by the melt waters of northern glaciers as they advanced and retreated in at least four iterations over the last million years. The Mississippi River flowing southward from Minnesota was (and is today) a meandering river of oxbows and cutoffs, continuously eroding banks, redepositing soil, and changing paths. Its historic meandering is particularly apparent in western Alexander County, Illinois, where topographical maps show swirls and curves and an oxbow lake, Horseshoe Lake, where the river once flowed, south of Commerce, Missouri, and near the modern day Len Small levee. The upland hills of the Shawnee National Forest just north and west of the town of Olive Branch and north of Route 3 give way to a low-lying plain between the Mississippi and Ohio rivers. Historically, this region has been a delta, confluence and bottomlands dating back 30,000 to 800,000 years before present (BP) with many of the Illinois lands shown on the maps located on both sides of the Middle Mississippi River as its channel changed positions over time. As a result, the fertile farmland of western Alexander County soils (Bonnie silt loam, wet; Piopolis silty clay loam, wet; Karnak silty clay, wet; Petrolia silty clay loam; and the Cape and Karnak silt loams [Parks and Fehrenbacher 1968]) formed in alluvial and lacustrine deposits.

Hydrologically, the Ohio River is the main stream of the Mississippi River (figure 1). Today it runs along the borders of 6 states $1,520 \mathrm{~km}$ (981 mi) west from Pittsburgh, Pennsylvania, to the Mississippi River confluence at Cairo, Illinois, and drains lands west of the Eastern Continental Divide from the Appalachian Mountains encompassing all or part of 14 states. The Ohio River, a southwestern flowing river, was formed between 2.5 and 3 million years ago when glacial ice dammed portions of north flowing rivers. About 625,000 years ago, the ancient Ohio River, fed by the Green and Cumberland rivers of Kentucky, flowed through the Cache River Basin and was smaller than the current Ohio River (Cache River Wetlands Center 2013). At that time, the Wabash River (Indiana) had not yet formed, and the Tennessee River was not a tributary of the Ohio but was the main channel where the Ohio River is today.

During the Woodfordian period $(30,000$ years $\mathrm{BP})$, the floodwaters from the historic Ohio River Watershed drained into eastern Illinois via Bay Creek to the northwest and then west through the Cache River Valley (figure 1) to presentday Alexander County where it converged with the Mississippi River northwest of the Horseshoe State Conservation Area (Olson and Morton 2013a). The middle Cache River Valley is $2 \mathrm{~km}$ (1.3 mi) wide as a result of the previous river having been much larger since it carried waters from the ancient Ohio River Valley in addition to the local waters from the upper Cache RiverValley to the Mississippi River.

Extensive deposits of gravel and sand, some as deep at $49 \mathrm{~m}(160 \mathrm{ft})$, rest on the bedrock floor of the middle and eastern portions of valley (Cache River Wetland Center 2013) and offer evidence of glacial flooding, which carved the valley deeply into the bedrock and then, as the water receded, back filled the valley with sediments. With increasing sediment fill and changes in climate, the Ohio River shifted away from the Cache River into its present course. This event probably took place between 8,000 and 25,000 years BP (Esling et al. 1989). As a result, the Cache River became a slow-moving stream with extensive isolated, low swampy areas (sloughs) (figure 2) with a water table that ebbed and flowed with seasonal precipitation.

The upper and middle sections of the Cache River Valley, the Main Ditch (figure 3) and Bay Creek, are located in the ancient Ohio River Valley where river water crossed through the state of Illinois approximately 10 to $20 \mathrm{~km}$ (6 to $12 \mathrm{mi}$ ) north of the present Ohio River position (figure 1). The Cache River Valley is deeper and at a lower elevation (between 


\section{Figure 1}

Map of Cache River Valley in southern Illinois, including Bay Creek, Post Creek Cutoff, and breached Karnak levee.



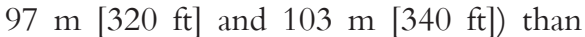
would otherwise be expected in a slowmoving swampy river system. The New Madrid Fault runs under and near Karnak and Ullin, Illinois, and the Cache area elevation does not fit with the rest of the area. Steve Gough, a land use change-overtime expert, has suggested a large section under the Cache River Valley sank during a major earthquake about $900 \mathrm{AD}$ (Gough 2005). The cypress trees in the Cache River Valley swamps are up to 1,000 years old, which would be consistent with this time estimate.

\section{TO 1915 POST CREEK CUTOFF}

The Cache River Basin occupies much of the valley, draining 209,914 ha $(524,786$ ac) while meandering $170 \mathrm{~km}(110 \mathrm{mi})$ throughout southern Illinois before emptying into the Mississippi River through a diversion ditch southwest of Mounds, Illinois (Guetersloh 2002). In 1905, 100,000 ha $(250,000 \mathrm{ac})$ of the Cache River Watershed was considered to be too wet and worthless for farming. The Cache River Drainage District was created in 1911 with the specific purpose of constructing the Post Creek Cutoff to drain the northern region of swamps and sloughs to create agricultural lands (Treacy 2011). The Post Creek Cutoff (figures 1 and 4) was constructed between 1912 and 1915 and rerouted the upper Cache River water into the Ohio River a little southeast of Karnak, Illinois (figure 1). By 1916, the $7.1 \mathrm{~km}(4.8 \mathrm{mi})$ long cutoff was $9 \mathrm{~m}$

\section{Figure 2}

Grassy Slough Preserve of Karnak and middle Cache River.

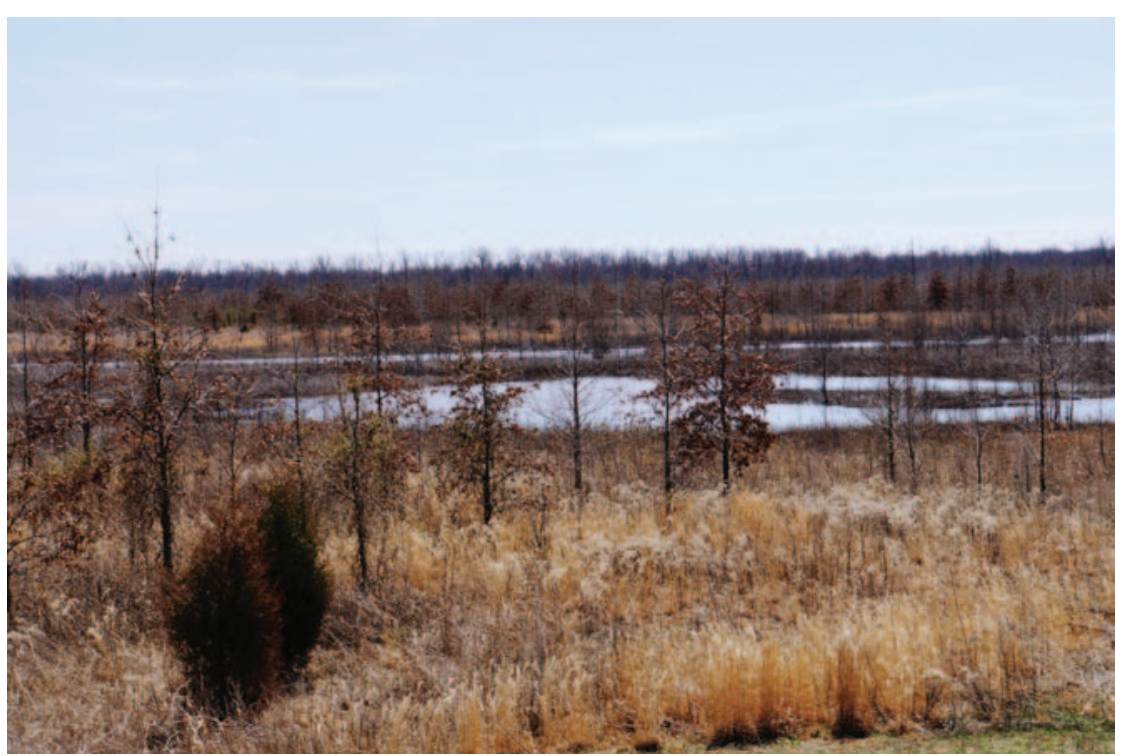

(30 ft) wide and $3 \mathrm{~m} \mathrm{(10} \mathrm{ft)} \mathrm{deep} \mathrm{(Treacy}$ 2011) and diverted $60 \%$ of the upper Cache River water due south and into the Ohio River. The Post Creek Cutoff gradient was $30 \mathrm{~cm}$ (12 in) per $1.55 \mathrm{~km}(1 \mathrm{mi})$. Near Grand Chain bridge (figure 4), the diversion has become a canyon in size. The 


\section{Figure 3}

Main Ditch, which drains agricultural lands.



\section{Figure 4}

The Post Creek Cutoff dug in 1912.

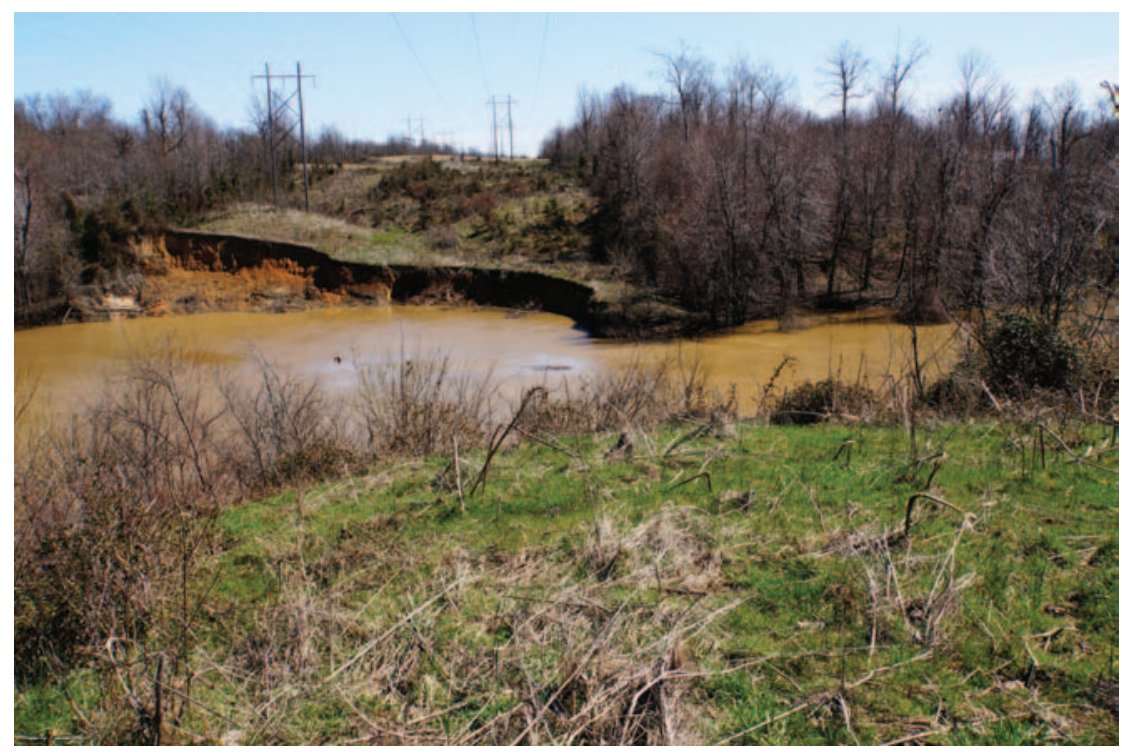

steep gradient and straight channel accelerated flows and started a severe erosion process; the channel is now $60 \mathrm{~m}(200 \mathrm{ft})$ wide and $19 \mathrm{~m}$ (64 ft) deep and represents severe gully advance and formation.

\section{MAIN DITCH}

Following the completion of the Post Creek Cutoff, the Main Ditch (figure 3) and other laterals were constructed
(USACE) built a higher structure that has since prevented such flows (Gough 2005).

The Main Brothers Box and Lumber Company used the Main Ditch and side ditches to float logs to a sawmill in Karnak where the logs were stored in a pond. Increased water velocities through the Post Creek Cutoff and laterals resulted in headward gully migration, scoured channels, and eroded banks $31 \mathrm{~km}$ (20 mi) up the upper Cache River, the Main Ditch, laterals, and streams. When the swamp levels were higher than the river, the natural levee, which separated the swamp and the river, degraded and underground piping occurred with gullies threatening to drain Heron Pond as well as other swampy areas.

As the Main Ditch (figure 3) and Post Creek Cutoff (figure 4) deepened and widened, so did many side streams and ditches. These laterals became gullies, some more than $1.55 \mathrm{~km}$ (1 mi) long extending into adjacent farm fields, which created field equipment access problems and loss of usable farmland. The Main Ditch and Post Creek Cutoff lowered the water table and resulted in loss of natural springs. Subsequently, these changes in hydrology have led to significant changes in natural plant and animal communities. The ditches drained water out of Black Slough and reduced the natural flood retention capabilities. Large silt deposits carried by the gullies and series of laterals ended up at the mouth of the Post Creek Cutoff (figure 4) and washed into the current Ohio River. Annual dredging is required to keep the Ohio River navigation channel deep enough for river traffic.

The approach taken to convert the Cache River Valley from forested wetlands to agricultural use was the one used to drain the Big Swamp southwest of Cape Girardeau, Missouri, and west of Commerce, Missouri (figure 1), for agricultural use from 1914 to 1928. Both areas required extensive drainage ditches before the timber could be removed and levees constructed to control the floodwaters. The bottomland alluvial soils are similar in both the Big Swamp and Cache River Swamp, but the source of the alluvial sediment is different. The Big Swamp was flooded by the ancient Mississippi River, and the Cache River Swamp was 
flooded by the ancient Ohio River. These two swamps joined at the confluence of the rivers in the area west of Horseshoe Lake and south of Commerce, Missouri, which is 35 river miles north of the current confluence. This occurred before the Mississippi River created a new channel at Thebes Gap to the east of Commerce, Missouri, and the Ohio River rerouted south joining the Tennessee River at Paducah, Kentucky (figure 1), after the last glacial advance.

\section{MISSISSIPPI RIVER DIVERSION}

In 1950, $18 \mathrm{~km}(11 \mathrm{mi})$ north of the lower Cache River's natural mouth at the Ohio River, a diversion channel and dike diverted the middle section of the Cache River directly into the Mississippi River (figure 1). The dike on the northeast side of the Mississippi River Diversion prevented the middle Cache River water from entering the last $18 \mathrm{~km}(11 \mathrm{mi})$ of the old Cache River channel. There was also a levee built on the south side of the lower Cache River channel, and the lower Cache River now drains through a gate and into the Ohio River above Cairo.

1952 KARNAK LEVEE AND 2002 BREACH

At the point where the Post Creek Cutoff diverted the upper Cache River directly south to the Ohio River a floodgate was installed in the Karnak levee built in 1952 (figure 5). When the upper Cache River levels were high, the floodgate was opened, and water flowed west through the middle Cache RiverValley and channeled into the Mississippi River Diversion. Land clearing and drainage efforts increased soil erosion and sediment transport. During the 1970s and 1980s, $30 \mathrm{~cm}$ (12 in) of sediment was deposited near the end of the Post Creek Cutoff. As the Post Creek Cutoff deepened and widened, it resulted in the upper Cache River water flowing directly into the cutoff and bypassing the middle Cache even when the Karnak gate was open.

In 2002, the fifty-year-old Karnak levee gate suffered a catastrophic failure during the spring flood season. The levee breach and gate failure resulted in dropping water levels in the middle Cache River. The effect of this failure (figure 5) is that the gate is now open all the time and cannot be closed when the middle Cache River experiences high water. During these high water events, the direction of the water reverses, and it flows east through the Karnak breach and into the Post Creek Cutoff to the Ohio River. When the water level in the middle Cache River drops below the Post Creek Cutoff water level, the flow resumes its westerly travel to Mississippi River via the 1950 Diversion. As a result of the Karnak breach, which has not been repaired, it is more difficult to control water levels, and the middle section of the Cache River is subjected to increased risk of flooding.

The middle section of the Cache River Valley, between the Karnak levee breach and the Mississippi River Diversion and dike, reroutes the water into the Mississippi River. The northern extension (dike) of the lower Cache River levee blocks the middle Cache River from entering the old channel of the lower Cache River. Now, only local lower Cache River Watershed water passes through the old channel and drains through a gate in the Ohio River

\section{Figure 5}

Karnak levee breach, which allows Cache River floodwaters to pass to the Mississippi River Diversion.

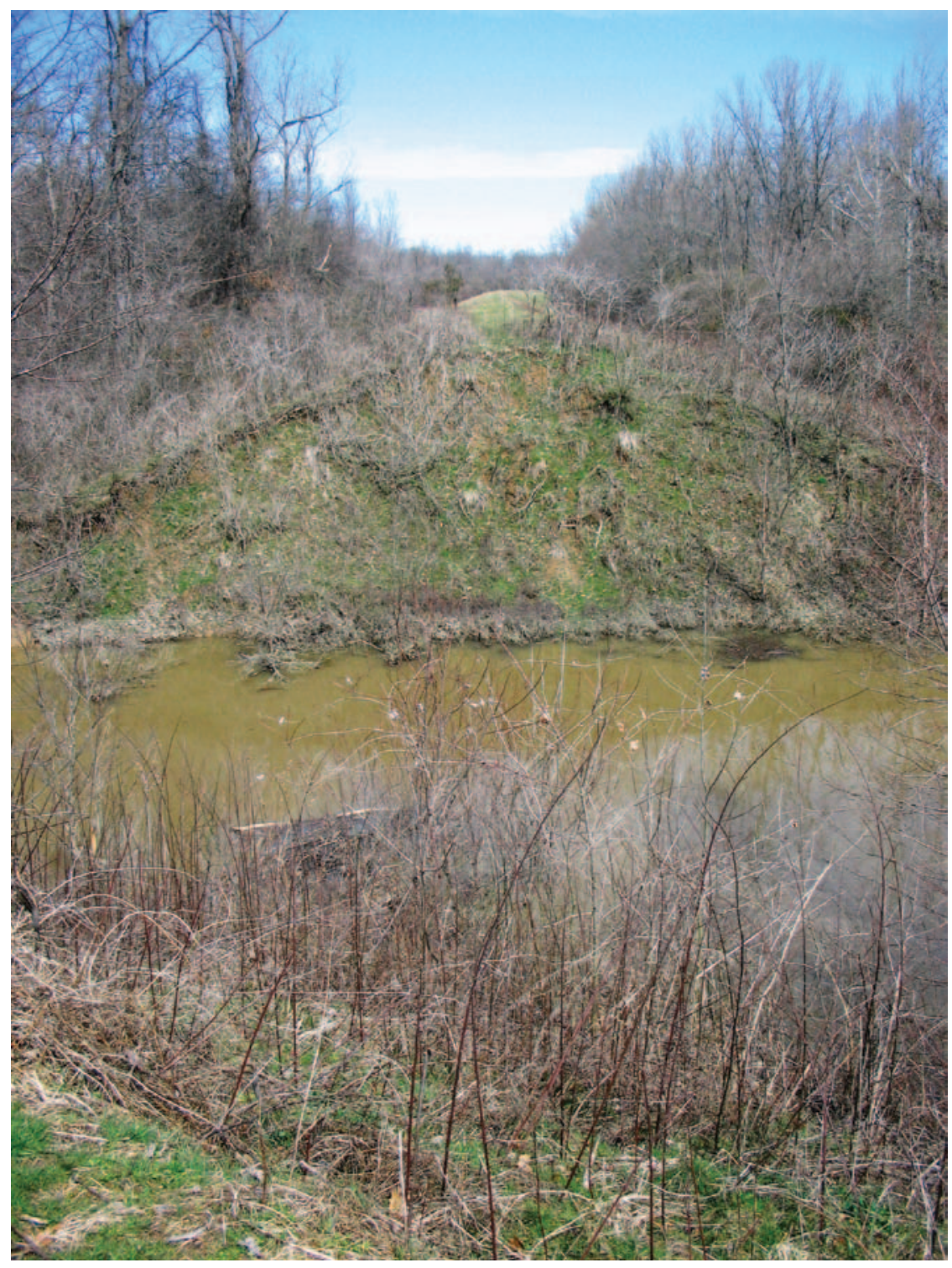


levee south of Mound City and north of Urbandale. Thus, the current 143 km (92 mi) long Cache River (figure 1) is dissected with the upper section draining into the Ohio River through the Post Creek Cutoff, the middle section draining through the diversion to Mississippi River, and the lower section of Cache River draining into the Ohio River. The lower Cache River is in the old channel with the levee on the south side of the river.

\section{THE GREAT FLOOD OF 2011}

In April of 2011, as the Ohio River approached the record high of $100.7 \mathrm{~m}$ (332.2 ft) above sea level, it backed up water into Bay Creek at Golconda, Illinois, and pushed into the eastern-most reach of the ancient Ohio River Valley entrance. The Reevesville Levee, between Bay Creek and Main Ditch held and blocked the Ohio River floodwaters from entering the Main Ditch and flooding the middle Cache River Valley from the east (figure 1). However, $62 \mathrm{~km}$ (40 mi) downstream, as the Ohio River rose above flood stage, it was able to enter the Post Creek Cutoff and flow north into the Upper Cache River Valley and Main Ditch and flood agricultural lands and the cypress swamps. Concurrently, water poured into the middle Cache River Valley through the previously breached (2002) Karnak levee (figure 5). The Ohio River floodwaters then flowed west into the middle section of the Cache River Valley and toward the town of Olive Branch (figure 1) and Horseshoe Lake prior to the Len Small levee breach which occurred on the morning of May 2, 2011. At the time of the Len Small levee breach, the Mississippi River was approaching the peak of 100.7 m (332.2 ft) (Camillo 2012; Olson and Morton 2013a). The elevation of the water in Horseshoe Lake is normally 97.6 $\mathrm{m}(322 \mathrm{ft})$ so there was a potential gradient of $3 \mathrm{~m}(10 \mathrm{ft})$. However, the Ohio River water coming through the middle Cache RiverValley was already causing the Horseshoe Lake level to rise. Horseshoe Lake flooding from the Len Small breach (Olson and Morton 2013a) occurred at a time when the Ohio River was $6.7 \mathrm{~m}$ (22 ft) above flood stage, and floodwaters passed through the Karnak levee breach (figure 5). These floodwaters eventually drained back into the upper Mississippi River near Route 3, through the diversion (figure 1), and eventually back through the Len Small levee breach.

Approximately 400 ha $(1,000 \mathrm{ac})$ of agricultural land north of $18 \mathrm{~km}$ (11 mi) lower Cache River levee was flooded as a result of the flood gate (figure 1) being closed at the Ohio River levee. This caused a backup in the lower Cache Creek floodwaters, which flooded the adjacent forest-covered alluvial soils (like Bonnie silt loam, wet; Piopolis silty clay loam, wet; and Karnak silty clay, wet) and flooded the slightly higher cultivated soils (such as Petrolia silty clay loam and the Cape and Karnak silt loams). These cultivated soils drained by the middle of June of 2011 and were planted to soybeans (Glycine max L.).

The floodwaters left a thin silt and clay deposition on the agricultural lands and crop residue when they receded. These coatings included significant amounts of soil organic carbon (C), microbes, and pathogens (Olson and Morton 2012; $2013 \mathrm{~b})$. After the coatings dried, they were incorporated into the topsoil layer of the alluvial soils using tillage equipment. The mixing in of sediment into the topsoil likely resulted in little significant loss of soil productivity (Olson 2009; Olson and Lang 2000).

There was little significant soybean damage or yield reduction on lands outside the levees along the Mississippi, Cache, and Ohio rivers since the flooding occurred during the nongrowing season. Had winter wheat (Triticum aestivum L.) been planted in the fall of 2010, the wheat crop would have drowned. Illinois farmers are aware of the flooding potential, especially in the winter and early spring, so they do not plant winter wheat. Consequently, there was no crop loss in April and May of 2011.

Local floodwater in the lower Cache River Valley, south of the Mississippi River Diversion and dike, could not flow back into the Ohio River since it was blocked by the Cache River levee on the south side and by the closed gate at the Ohio River levee. Thus, water backed up and flooded forested and agricultural lands along the lower Cache River and north of the Cache River levee.

\section{CONCLUSION}

The Cache River Basin, which once drained more than 245,640 ha $(614,100$ ac) across six southern Illinois counties, has changed substantively since the ancient Ohio River receded leaving a slow-moving, meandering river; fertile soils and productive farmlands; deep sand and gravel deposits; sloughs and uplands; and one of the most unique and diverse natural habitats in Illinois and the nation. Land use changes, diversion ditches and levees, loss of wetlands and flood holding capacity, internal channelization of the Cache River and tributaries, and an ever-changing climate have altered the hydrology of the valley, redistributed soil from fields and ditch banks into the river, and transported tons of sediment during flooding events into both the Ohio and Mississippi rivers. As the 2011 Ohio River floodwater reclaimed its ancient floodway, the extent of these hydrologic changes and their social, economic, and environmental impacts have become more apparent.

The Great Flood of 2011 lends urgency to the reevaluation and implementation of the Cache River Watershed Resource Plan completed in 1995. Nine resource concerns were identified: erosion, open dumping, private property rights, water quality, continuation of government farm conservation programs, Post Creek Cutoff, open flow on the Cache River, dissemination of accurate and timely information throughout the watershed, and the impacts of wildlife on farming and vice versa. Most of these concerns continue to need to be addressed. Since that plan was created, the Karnak levee, no longer managed by USACE, was breached in 2002 and not repaired, likely due to cost since it is ineligible for federal funding. The Karnak levee is now in the Big Creek Drainage District Number 2. The Cache River Wetlands Joint Partnership, composed of Ducks Unlimited, Illinois Department of Natural Resources, USDA Natural Resource Conservation Service, and US Fish and Wildlife Service, are considering a restoration project that would repair the Karnak levee breach (figure 5) as part of its efforts to restore low Cache River flow. Since 2002, two reports on 
the Karnak levee repair project have been prepared by Cache River Watershed Resource Planning Committee (Treacy 2011) and made available to the public by the Center for Watershed Science at the Illinois State Water Survey. It is not clear what, if any, impact the 2011 Ohio River flooding of the Cache River Valley will have on the plans to eventually repair the Karnak levee breach.

Early snow melt and excessive precipitation resulted in the Ohio River reaching $18.7 \mathrm{~m}(61.7 \mathrm{ft})$ on the Cairo gage in May of 2011 and created a mighty challenge for residents of southern Illinois, local Soil and Water Conservation Districts, state agencies, and the USACE in their attempts to manage the "big" rivers, Ohio and Mississippi, and the much smaller Cache River so as to protect towns, farmsteads, agricultural lands, and wetlands of the Cache River floodplain. As the repair and rebuilding of the valley infrastructure is undertaken, there will need to be a significant investment of human and financial resources to reduce the impacts of future catastrophic events.

\section{ACKNOWLEDGEMENTS}

Partial funding for this research is through USDA National Institute of Food and Agriculture Heartland Regional Water Coordination Initiative under agreement 2008-51130-19526. Additional Hatch 65-372 NRES funding support was received from the Director of the Illinois Office of Research, College of Agriculture, Consumer, and Environmental Sciences, University of Illinois, Urbana, Illinois.

\section{REFERENCES}

Cache River Wetlands Center. 2013. Cache River - State Natural Area. Cypress, IL: Illinois Department of Natural Resources. http://dnr. state.il.us/lands/landmgt/parks/r5/cachervr.htm.

Camillo, C.A. 2012. Divine Providence: The 2011 Flood in Mississippi River and Tributaries Project. Vicksburg, MS: Mississippi River Commission.

Esling, S.P., W.B. Huges, and R.C. Graham. 1989. Analysis of the Cache Valley deposits in Illinois and implications regarding the late PleistoceneHolocene development of Ohio River. Geology 17(5):434-437.

Gough, S.C. 2005. Historic and prehistoric hydrology of the Cache River, Illinois. Unpublished report to the Cache River Joint Venture Partnership (JVP). Murphysboro, IL: Little River Research \& Design.
Guetersloh, M. 2002. Big Creek Watershed Restoration Plan: A Component of the Cache River Watershed Resource Planning Committee. Prepared for the Cache River Watershed Resource Planning Committee. Springfield, IL: Illinois Department of Natural Resources.

NOAA (National Oceanic Atmosphere Administration). 2012. Historic crests. Cairo, IL: National Weather Service, Advanced Hydrologic Prediction Service.

Olson, K.R. 2009. Impacts of 2008 flooding on agricultural lands in Illinois, Missouri, and Indiana. Journal of Soil and Water Conservation 64(6):167A-171A, doi:10.2489/jswc.64.6.167A.

Olson, K.R., and J.M. Lang. 2000. Optimum crop productivity ratings for Illinois soils. Bulletin 811. University of Illinois, ACES, Urbana, IL, Office of Research.

Olson, K.R., and L.W. Morton. 2012. The Impacts of 2011 induced levee breaches on agricultural lands of Mississippi River Valley. Journal of Soil and Water Conservation 67(1):5A-10A, doi:10.2489/jswc.67.1.5A.

Olson, K.R., and L.W. Morton. 2013a. Impact of the Len Small levee breach on private and public Illinois lands. Journal of Soil and Water Conservation 68(4):89A-95A, doi:10.2489/ jswc.68.4.89A.

Olson, K.R., and L. W. Morton. 2013b. Restoration of 2011 flood damaged Birds Point-New Madrid Floodway. Journal of Soil and Water Conservation 68(1):13A-18A, doi:10.2489/jswc.68.1.13A.

Parks, W.D., and J.B. Fehrenbacher. 1968. Soil Survey of Pulaski and Alexander counties, Illinois. Washington, DC: USDA Natural Resource Conservation Service.

Treacy, T. 2011. The Cache: A disconnected river. Sierra Club Illinois website. Resource Plan for Cache River Watershed, Cache River Watershed Resource Planning Committee, December 1995. Cache River Watershed. http://sierraclubillinois. wordpress.com/category/wild-illinois/cache/. 